\title{
Identification of Leadership Role for the Independence and Sustainability of Private Course Institution
}

\author{
Sri Wahyuni (Corresponding author) \\ Dept. of Non Formal Education, State University of Malang \\ J1. Semarang 5, Malang 65145, Indonesia
}

Tel: 62-341-552-888Ｅ-mail: sri.wahyuni.fip@um.ac.id

Endang Sri Redjeki

Dept. of Non Formal Education, State University of Malang

Jl. Semarang 5, Malang 65145, Indonesia

Tel: 62-341-552-888 E-mail: endang_djekium@yahoo.co.id

$\begin{array}{lr}\text { Received: January 18, } 2018 \quad \text { Accepted: February 9, } 2018 \quad \text { Published: February 20, } 2018 \\ \text { doi:10.5296/ijld.v8i1.12496 } & \text { URL: https://doi.org/10.5296/ijld.v8i1.12496 }\end{array}$

\begin{abstract}
This study aimed at explaining the role of leadership in enhancing the independence and the sustainability of private course institution. This study employed a phenomenology research design to explore the leadership of Art House "Windyas Club" institution. Art House "Windyas Club" was a private course institution teaching children art, painting and coloring, located in Sukun Subdistrict of Malang City. The institution has been running independently for more than 13 years. The data were collected through deep interview, observation and documentation. An inductive analysis model used as the analysis technique. The result of this study shows that: (1) independence is regarded as an the result of deep interpretation of life goals and efforts in life and the manifestation of appreciation upon certain efforts in life (2) leaders maintain the independence and the sustainability of the institution by applying a servant leadership which includes: (1) as the creator or conceiver, in which leaders should create innovation and design any program; (2) as the mediator, in which leaders should act as the resource linker, linking the institution with stakeholders to manage the institution; (3) as the servant in which leaders should be willing to directly provide services for the clients; (4) as a role model, in which leaders are required to share positive values to all of the staffs and teachers including the values of sincerity, prayers, hard work, creativity, good deeds, and gratitude.
\end{abstract}

Keywords: Leadership role, independence, private course institution 


\section{Introduction}

Education orientation in the global era has shifted to human empowerment which should be done through education and traning in various choices, levels and fields. Private course appears to be an alternative to fulfill the needs of the society. Private course institutions offer solutions to improve society's life skills. Based on the executive information, it can be seen that the graduates of private course program have higher opprotunity to get recruited for better job as presented in Table 1 .

Table 1. The Recapitulation of Prive Course Alumni

\begin{tabular}{lll}
\hline No & Alumni Status & Total \\
\hline 1 & Pursuing Higher Education & 20.532 \\
2 & Working & 71.539 \\
3 & Being Entrepreneurs & 14.471 \\
4 & Waiting for Job Placement & 50.161 \\
\hline
\end{tabular}

The table shows that the alumni of private course institution have better opportunity to get recruited which gives positive contribution to the unemployement issue. It also implies that the presence of private course institutions is important to enhance the quality of the human resource.

Act number 20 of 2003 about the National Education System Article 26 verse (4) states that private course institutions are part of non-formal education institutions along with other institutions including training providers, study group, Ccommunity Learning Center, Conferences and similar units. Private course institution have been playing important role in empowering the society such as found by Adawiyah (2012) who stated that private course institutions produced ready-to-work graduates recruited by companies. As stated in Act number 20 of 2013 Article 26 verse (5), private course institutions should fulfill the needs of knowledge, skills, life skills, and improve the attitudes of the society to have better quality to perform their job, run their business or to pursue for higher education (Law of National Education System, 2003).

According to the Directorate of Private Course Institution, The Directorate of the General Ministry of Non-formal and Informal Education of 2015, there were 13.600 private course institutions. However, data related to the real condition of the institutions were not yet available. The government often provide blockgrant fund for private courseinstitutions using the "proposal-based" model, yet problems related to the funding appeared including the unclear mapping of the performance and the capability of the institutions in running their program. Private course institution as a part of private institution has its own characteristic. Suyitno, Sonhadji, Arifin \& Ulfatin (2014) stated that the ability of some private vocational schools to survive the intense competition with public vocational schools is an interesting 
phenomenon. Therefore, some institutions failed at receiving the fund, which had them managed their own funding independently. In this situation, private course institutions are required to set up their own strategies to maintain their performance.

It is a manager's responsibility to manage the sustainability of a private course institution.. A manager of a private course institution holds a huge responsibility to run the company's program. Change of management of an organization depends on the transformational leadership of an intitutional manager (Regina, 1999:80). Reeves (2006:34) stated that the leader faced with a crisis, needed to make some profoundly important decisions about products, markets, and people, and then he had to flawlessly execute those decisions. Thus, a manager should always consider applying the most efficient strategy or known as the "do things right" (Vijay, 1996:7). Effective leadership leads to effective and efficient process to achieve the goals of a company. This view is also supported by Oedjo (2004) who mentioned that a school headmaster is one of factors that lead a school to achieve the goal in the most effective and efficient way. Therefore, private course institutions should apply an effective leadership and strong leadership role in order to achieve the intended goal.

Effective leadership is also important in strengthening a private course institution's independence and sustainability, allowing the institution to provide excellent services for the society. The has been insufficient number of studies on the role of leadership in private course institutions. Whilst, a lot of studies on formal education have been conducted. Considering the importance of private course institutions for the society and the importance of improving the quality, independence, and sustainability of the institutions, thorough study on the role of leadership in the management of private course institutions was considered necessary.

\section{Method}

This study was done using qualitative approach and phenomenology research design was applied. Qualitative research is a naturalistic research which attempts at explaining certain phenomena through an inductive analysis instead of simply applying generalization process (Lincoln \& Guba, 1985; Bogdan \& Biklen, 1998; Faisal, 2006; and Creswell, 2009). Qualitative phenomenology study was considered relevant to use in this study, as stated by Spradley that this type of research can be used to study a natural phenomena in order to find the meaning and facts behind certain phenomena. This study was conducted in Art House "Windyas Club" located in Perumahan Griya Tirta Aji A1, Jl. Pelabuhan Bakahuni Bakalan, Krajan, Sukun Subdistrict, Malang City. Data of this study were collected from the informant who was the leader of the institution. The data were collected through in-depth interview, observation and document analysis. These three data collection technique were applied based on the the current need during the data collection in order to obtain detailed and deep data related to the leader's insight in solving certain problem (Bogdan \& Biklen, 1998; Faisal, 2006:5).

Unstructured interview should be done using open-ended questions (Yin, 2011). Researchers should understand informant's interests (Bogdan \& Biklen, 1998:46) such as by letting the informant determine the time and place to conduct the interview. Participatory observation 
was done in which the researchers acted as a passive participant. As pointed out by Susan Stainback in Sugiyono (2010:311), passive observation requires researchers to come into the field, observe and listen to any conversation that occur, investigate and feel the ambiance of the field. Document study was employed to obtain additional data to complete the data which were previously obtained from interview and observation, strengthening the credibility of the data since documents provide relevant information about events that happened in the past (Sugiyono, 2010:329).

An interactive data analysis model was employed as suggested by Miles \& Huberman (1992) which consisted of three phases; data reduction, data representation and drawing the conclusion. Validity test was administered by measuring the credibility of the data using triangulation of the data collection, source of the data, colleagues discussion and member check. Method triangulation was done by confirming the data obtained from the interview, observation and document study to make sure that the data were valid and provided the intended information as suggested by Reynolds \& Nasution in Mantja (2006). The researchers also conducted member check by asking for informant's feedback in order to strengthen the credibility of the data (Ary, et al, 2002). In this phase, the informant provided data or information including researchers' interpretation upon the recoded data by cross-checking them to other informants.

\section{Results}

\subsection{The Essence of Independence and Sustainability from Leaders'Perspectives}

Similar to other education institutions, private education institution also hold key roles in improving the quality of the human resources. The presence of private course institutions is highly important especially for leaders and the owners. The success in running a private course is also a pride for the owners, leaders, and managers of the institution. This phenomena was also experienced by owner, leaders and members of Sanggar Seni Windya's $C l u b$ as a private course institution providing education on art. The owner of the club stated that this club is an important part in his life since it is a realization of life goal, worship, happiness, tranquility, and compassion for the religion and the parents (W/CW/201017). This club is considered as the air for owner's life and it gives particular meaning in life for the owner. In line with the statement, the staffs of the club also stated that the owner is always excited everytime there is an event, and the owner always encourages the staffs to worship the God (W/TY/201017). Compassion toward Windya's Club is reflected in all of the programs set by the institution. The logo of this club was also specially designed to reflect a philosophy. The owner stated that the logo is heart-shaped with two different-characterized children holding blue charter (W/CW/211017).

The deep feeling for the club has led the leader to always do the best effort in keeping the club alive and to give proper non-formal education for the society. When the owner was asked to share the opinion on the sustainability of the club, she stated that sustainability in Windya's Club is seen as a trust and blessing. The owner explained that best efforts have been done to keep the Club alive since the club is also a big part of the owner's life, worship, tranquility, and happiness. The club is also a reflection of gratitude for being gifted with the 
sense of art from the God, therefore, running the club is a worship to the God (W/CW/211017).

Sustainability of Windya's Club is also seen as a chance to share treasure for the younger generation. The owner stated that the children, grand children, big family are expected to continue the owner's expectation to build a professional art school in order to provide people grow their art talents even if they are from poor families (W/CW/210917). This statement reflects owner's huge expectation for the club be run independently. The staffs also stated that the owner always reminds them to perform their jobs in order to worship the God Almighty and to help those who are in need (W/TY/211017).

Owner also expects that the club is run independently considering the leaders have committed to run the club as an independent institution. Leaders shared their views related to the decision. They decided to be independent in order to get the freedom to be as creative as possible without being limited by bureaucracy or any rules. Members also wished to be more creative, innovative, and always stay highly motivated. Besides, the independence makes grow gratitude to the God for being free to express themselves without being burdened by regulations and they are able to practice their preferred way of teaching without being ruled by certain curriculum or obligation to write formal reports (W/CW/221017).

Independent and sustainable private course institutions also appear to be more trusted by the society. This can be seen from some achievements made by the club such as the chance to work with other institutions to held competition supported by various parties. Member of the club were often appointed to become adjudicators of various art competition such as coloring, drawing, painting, calligraphy art, and poster competition. Sometimes, the leaders of Windya's club were also invited as keynote speakers in various events such as an event held to improve the creativity of teachers and students in Malang city (SD/230917).

From the explanation, it can be implied that independence and sustainability have certain meaning for Windya's Club. The meaning can be categorized into achievement and prestige. As an achievement, independence and sustainability is an interpretation of the life goal and life efforts that raise willingness to (1) cherish the club sincerely, sacrifice for the club and make efforts to maintain the performance of the club; (2) become more creative and innovative in order to obtain stronger trust from the society. Hence, even though the club is not funded by the government, the club is still able to run; (3) make more effort to improve the capability of the club to make sure that the club can be inherited to the younger generation. Whereas, as a prestige, independence and sustainability are also the manifestation of appreciation upon efforts made by the leaders of an institution.

\subsection{The Function of Independence and Sustainability of the Institution}

Leaders of an institution are the motor of an organization. The presence effective and strong leaders is highly important for a private course institution. The fact that the competition among private course institutions is quite tight, leaders are required to act as the "brain" of the institution in order to keep the institution sustainable. Leaders should carefully think of ways to get the society interested in joining the club, and to give better education and service 
by administering various interesting programs. Windya's club always tries to conduct its programs independently without receiving fund from the government. Therefore, leaders of this institution have to act as conceivers and creators in every event. Leaders of the institution stated that they always directly participate in any event held by the club as conceivers, creators, directors even sometimes they were the main actors in shows (W/CW/22102017).

Windya's Club also always tries to teach the society skills that they can use to create their own job opportunities. It is stated that Windya's Club provides new job opportunities with highly qualified human resource. In the future, the club will grow strong enough to establish an independent art school as a professional non-formal education institution that the nation can be proud of through the logo Seni Hati Anak Indonesia, even it can be developed into an international-class art school through the tagline "Let's Get Wonderful World by Art" (W/CW/21102017). The leaders of Windya's Club explained the importance of having certain tagline as a motivation for the members to achieve the vision and missions of the institution. "Lets Get Wonderful by Art" contains an energy that strengthens the independence of the institution.

Playing roles as creators and conceivers at the same time requires adequate competence, knowledge and skills. In order to enhance the capability, leaders of the club always improve their competence and capability by attending both formal and non-formal education on the field. It is stated that some graduates of the club successfully established their own business. The leaders also continued their education to higher level even some attended graduate schools. The club also successfully funded 3 students to reach their higher education (W/CW/22102017). The staffs also stated that the owner also continued her study to a higher level independently (W/ST/23102017).

Besides improving their own capability, leaders of the club often work together with other parties or stakeholders. Most of the events held by the club were supported by some departments. From the documents collected by the researchers, it can be seen that Windya's Club often involved the village officers, sub-district officers, PKK Malang City, City's Library, The Department of Social Welfare and Culture, Bank Indonesia Jakarta, Ramayana, MOG Malang, Araya, PT. Pinastika Honda Malang, Radar Malang, Pawnshops, Andhong Property, PT. Indana Paint, Stimuna, Artline, Fabercastel, Morinaga, IGTKI, Street Child, Jaringan Kemanusiaan Jawa Timur JKJT, Gramedia, Himpaudi, Unisma, Brawijaya University and many others (D/21102017)

Windya's Club always offers best serve for the students. Leaders' capability allowed them to directly teach the members of the club. It is stated that leaders always put the best effort to teach the students art skills such as drawing, coloring, cloth painting, story telling, singing, recycling, creating souvenirs and fashion (W/CW/20102017). This statement is supported by the result of the observation which shows that huge number of students' creation were put on display on the wall (O/20102017). Leaders do not only practice teaching, but they also do their best to help students' life by providing allowances for orphans or for students from poor families, even more some students were sent to continue their study to higher level. The owner stated that there were a number of students who received the fund to continue their 
study from the elementary level up to the undergraduate level (W/CW/20102017). In an interview with a student of the club, a student shared an interesting story. It is stated that the student has been receiving fund to help with her education from the elementary school until the university level (W/ST/23102017). Leaders always try to give equal service without any discrimination.

In any condition, Windya's Club always prioritize excellent service and quality. There is no discrimination in teaching the students art. Students were treated fairly regardless of their background, even some of them could not afford to pay for the tuition. Cross-subsidiary system was applied to help students in need in the forms of free books and free courses. It is considered a blessing that the club gained huge trust from the society even without doing massive advertising using brochures. Even more, some schools have asked the club to conduct some programs together (W/CW/20102017). Leaders also stated that there was no significant obstacles in giving their services to their students since cross-subsidiary system was applied. Poor students were helped by other students to pay their tuitions. There were some students who joined the education for free and students who paid the fee.

To lead is to influence other people to achieve certain agreed goals. Leaders of Windya's Club consistently makes efforts to achieve the goal. Leaders of the club emphasized on the importance of giving good examples and encouraging the students that they can be better than the leaders. Students were also motivated to always do good deeds, learn to be sincere, do prayers everyday, practice hard work, keep being creative, generous and thankful for everything (W/CW/21102017). Those principles show that the club always expose the students to positive attitudes as examples for all of the students as well as the staffs. Those positive values are the core of the leadership.

Based on the result of the data analysis, it can be concluded that organizational independence and sustainability are highly influenced by the role of the leaders. Leaders of Windya's Club played role as; (1) conceiver and creator, in which leaders are required to make good concept of the club's programs and create motivational tagline for the students and the staffs (2) mediator, in which leaders are the resource linker, linking the institution to prospective stakeholders to conduct some events; (3) as the servant who are willing to directly involve in giving service to the students; (4) as the example; in which all of the staffs should always be aware of 6 principles which are sincerity, prayer, hard work, creativity, generosity, and gratitude in performing their jobs.

\section{Discussions}

\subsection{The Essence of Independence and Sustainability for Owners of Private Course Institutions}

Private course institutions is one of non-formal education institutions that have different characteristics with formal education. Non-formal education has varied forms and program content. The purpose of non-formal education programs is vary, learners do not have strict requirements as well as formal education learners. The responsibility for the management and financing of non formal education belong to different parties, either by the government, 


\section{Macrothink}

social institutions, or individuals who organize educational programs. Sudjana (2004: 17) concluded that the differences of non-formal and informal education lies in various aspects of both the system and its implementation.

Independence and sustainability of private course institutions have two essences as an achievement and as a prestige. As an achievement, the presence of private course institutions for the leader is regarded as an interpretation of the life goal, and life effort which raise the willingness to (1) sincerely love the institution, make sacrifice, and always do what it takes to make the institution grow and develop; (2) always be creative and innovative in order to obtain and maintain the trust given by the society even without receiving fund from the government; (3) always make the best effort to keep the institution growing in order to be inherited to the future generation as the future leaders of the institution. Meanwhile, as a prestige, independence and sustainability are the manifestation of appreciation upon efforts in life done by leaders of private course institutions.

The result of this study proposes a new insight on the role of leadership in an independent institution to win the competition among other institutions. According to Kotler (2006:426), private course institutions can be classified as business organization. Kotler also classified public service sector into government-owned public service provider, non-profit non-government provider, business-based provider and manufacture. In this context, Windya's Club is included into non-profit organization. This can be seen from the sincerity of the owner and the leaders in running the organization to provide education services for the society.

Even though Windya's Club is a non-profit organization, but the club always improve its quality service. In line with Kotler's statement (1995:126), there were five approaches to the improvement of an organization including; creating favorable work atmosphere, improving the quality service, providing more facilities, offering new services, and applying better and more efficient management system. Leaders of Windya's Club always tries out new innovation and creations to obtain stronger trust from the society. Trust from the society is an important aspect to achieve since it determines the sustainability and the growth of an organization. Within the context of business management theory, trust from the society is referred as a consumer-perceived service quality which covers various dimensions of a service provider seen from the consumers' point of view (Jasfar, 2009:48). Gronroos (1990) that is illustrated in Figure 1. 


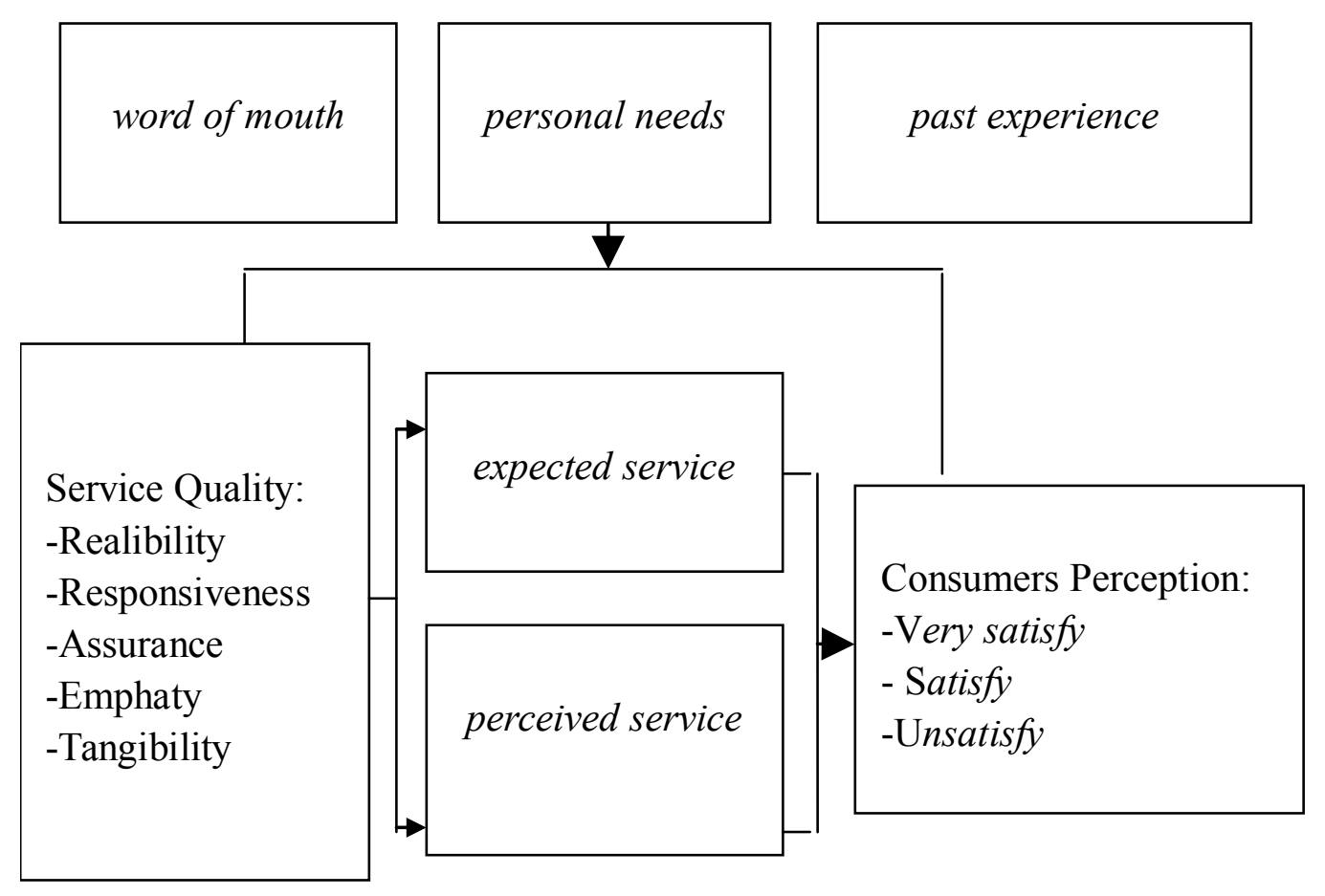

Figure 1. Consumer-Perceived Service Quality (Source: Fitzsimmons, 2001:44)

Figure 1 shows that the service quality is strongly influenced by consumers' expectation. As stated by Olson and Dover (in Zeithaml, 1993), consumers' expectation refers to customers' assumption before trying out certain service which is used as the standard in evaluating the service.

Efforts made by members of an organization give some contribution to the organization. Efforts can be regarded as a pride or the image of an organization. Seen from the theory of management studies, pride is one of aspects that influences the strategic value of an organization. Gronroos (1990) mentioned some dimensions of quality service seen from costumers' point of view, which are:

1) Technicaloroutcome dimension, related to what is offered by a service providerand what is received by the consumers.

2) Functionalorprocess related dimension, related to how a service is given, how it is offered and the how the service gives positive impressions from the consumers.

3) Corporate image, related to the image of a service provider among consumers. When consumers have initial positive impressions toward a provider, mistakes made by a provider in giving its service can be covered by the positive corporate image.

Positive corporate image and corporate sustainability interrelated. Therefore, an organization should always try to give positive impressions to the customers in order to obtain positive responses from the society. In the other word, corporate sustainability and independence are 
positive corporate image that distinct an organization from others.

\subsection{The Role of Leadership for Corporate Independence and Sustainability}

The result of this study shows that independence and sustainability of private course institutions are influenced by the role of leaders for the institution. In Windya's Club, leaders act as (1) conceiver and creator, (2) mediator, (3) servant, (4) example. This finding shows tha leaders' role is the manifestation of leadership based on humanity approach or emotional management. Within this type of leadership, there is a religious leadership style that starts from intrapersonal aspects to interpersonal aspects. This type of leadership allows leaders to be more responsible upon their function and position to give the best service for the society. Religious leaders with high commitment to the job always give the best service to the members of the organization in order to make great steps forward. According to Yukl (1998) leadership is a behavior of a person or individual to the process of giving meaning to the collective effort. Therefore it is needed a leader who has the overall competence to create a quality educational institution. Educational leaders have a great responsibility to play various roles as Usman (2010: 277) points out that the role of educational leader is as personal, educator, manager, administrator, supervisor, social, leader, entrepreneur and climator.

Affectionate leaders have strong compassion which is usually expressed in the form of deep attention to the members. The affection can be reflected by fulfilling the basic needs, interests, granting the wishes and expectations of the members. According to Danah Zohar, the writer of a book entitled The Spiritual Intelligence: SQ the Ultimate Intelligence, one of the indicators of spiritual quotient is the religious servant leadership. Some research show that world leaders who have been successful in bringing the organizations to the top of the success are mostly religious persons with high spiritual quotient. Successful leaders are usually highly competent and have strong integrity, open minded and have the best response to criticisms and always do good things for their selves as well as for the members of their organizations. Meanwhile, Reddin (in Sutarto, 2012:108) proposed a Three-Dimensional Model or the 3D model on this issue. This approach illustrates the existence of three groups of interconnected leadership styles that are basic styles, effective styles, and effectiveness in one unity The relationship between the three styles of leadership can be explained through Figure 2 .
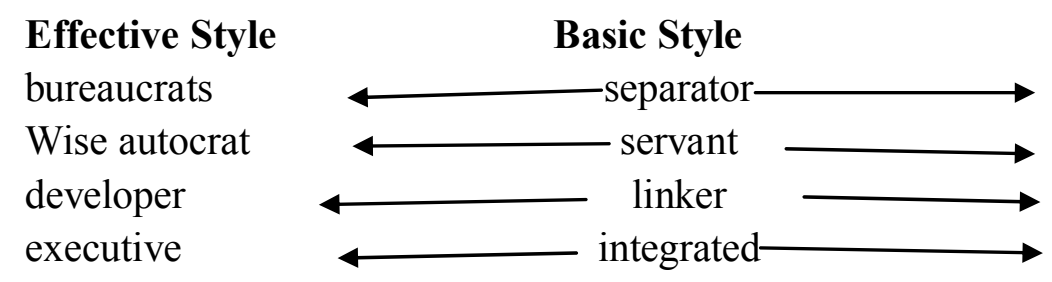

Effectiveness Style
runner
autocrat
advocate
compromise

Figure 2. Leadership Model “3-D model” Reddin 


\section{Ml Macrothink}

Based on the 3D model, leadership in Windya's Club is included as a dedicated, servant leadership, in which leaders are willing to do anything for the organization. Leaders of institutions willing to spend time to think about institutional development. The persistent leadership seeks opportunities for cooperation with other parties and supportive organizations. The leadership model by Bruce is categorized as authentic leadership that similar to transformasional, charismatic, servant, and religious leadership

Organization leaders should actively seek for opportunities as stated in Stonen theory in which leaders' role is classified into (1) leaders work together with other parties which reflects the responsibility of the leader as a team player, as members, staffs, colleague, or as a person outside work environment; (2) leaders are responsible and able to take responsibilities, which means that leaders should do their responsibilities including creating their tasks and administering evaluation to make sure that the goal is achieved; (3) leaders should synchronize the goal achievement and scale of priority in which leaders should always put the priority at first; (4) leaders should be able to make analytical and conceptual evaluation to precisely identify any occuring conflict; (5) leaders are mediators in any problems or issues that occur; (6) leaders are politician who should be able to influence other people and make compromises; and (7) leaders should take decisions and take the responsibility of them. According to Boy (2017) the role performed by the leadership of this private course institution is the leader's peak experiences that includes heightened sense of self, awareness of one's core values, deep connected attention, and being in full presence.

\section{Conclusions and Suggestions}

\subsection{Conclusions}

5.1.1 The Essence of Independence and Sustainability of the Private Course Insitution for the Leaders

Independence and sustainability are perceived by leaders as achievement and prestige. As an achievement, the presence of independent private course institution is the result of deep interpretation of life goals and efforts in life which are able to raise the willingness to (1) have sincere love for the institution, make sacrifice for the institution and the expectation to maintain and improve the institutions; (2) be creative and innovative in order to gain trust from the society even without receiving any fund from the government and in order to survive; (3) try to move the institution forward which later can be inherited to the younger generation. Meanwhile, as a prestige, independence and sustainability appear as the manifestation of appreciation upon certain efforts in life done by a member of the institution.

\subsubsection{The Role of Leadership for Corporate Independence and Sustainability}

Independence and sustainability of private course institution are strongly influenced by the role of the leadership applied in the institution. Windya's Club applies servant leadership style that covers some specific leadership roles; (1) as creator and conceiver, in which leaders are the decision makers and designers at the same time; (2) as mediator, in which leaders are the resource linkers, linking the institution with stakeholders to conduct events or programs; (3) as servant, in which leaders should be willing to sacrifice and directly involved in giving 
services for those who seek for those who want to learn; (4) as role model, in which leaders should always show positive values for all of the staffs and teachers in applying the 6 principles which are sincerity, prayers, hard work, creativity, good deed and gratitude.

\subsection{Suggestions}

\subsubsection{For Art House Windya's Club}

Servant leadership has been proven to give positive contribution to the institution. Therefore, it is suggested that Windya's Club use apply servant leadership style as the branding of the institution which also appears as an investment to the sustainability of the club.

\subsubsection{For Managers/Leaders of Private Course Institutions}

It is suggested that private course institutions pay attention to the leadership system applied in the organization and the roles that should be played by leaders of the organization considering the fact that leadership role strongly determines independence and sustainability of an institution.

\section{Acknowledgements}

This study was funded by The State University of Malang from PNPB Budget of 2017. The biggest gratitude is expressed for the Dean of the Faculty of Teaching Science and the Head of Non-formal Education Program who have given the chance to conduct this study. Gratitude also goes to owner, leaders, staffs and students of Windya's Club who have participated as the subjects of this study.

\section{References}

Adawiah, R. (2012). Peranan Lembaga Kursus dalam Pembedayaan Masyarakat di Kecamatan Balangan. Artikel (online). Retrieved Februari 12, 2017, from http://eprints.unlam.ac.id/id/eprint/75

Bogdan, R. C., \& Biklen, S. K. (1998). Qualitative Research for Education: An Introduction to Theory and Methods (p.46). Boston: Allyn and Bacon.

Borg, W. R. \& Gall, M. D. (2003). Educational Research: An Introduction (3rd. ed.). New York: Longman.

Boy, V. D., \& Maarten, J. (2017). The Role of Wilderness Experiences in Leaders' Development toward Authentic Leadership. Leadership \& Organization Development Journal, 38(8), 1144-1156. https://doi.org/10.1108/LODJ-06-2016-0153.

Bruce, J, William, A., \& Gadner, L. (2005) Authentic Leadership Development: Getting to the Root of Positive Forms of Leadership. The Leadership Quarterly Journal, 2(3), 315-338. https://doi.org/10.1016/j.leaqua.2005.03.001 get rights and content.

Creswell, J. W. (1994). Research Design: Qualitative \& Quantitative Approaches. Thousand Oaks, CA: Sage Publications, Inc.

Creswell, J. W. (2009). Research Design: Qualitative, Quantitative, and Mixed Methods 
Approaches (3rd, ed.). Thousand Oaks, CA: Sage Publications, Inc.

Direktorat Pembinan Kursus dan Pelatihan (2017). Rekap Informasi LKP Terbanyak Lulusannya. Retrieved July 12, 2017, from www.infokursus.net/sie/rekap-alumnus

Faisal, S. (1990). Penelitian Kualitatif: Dasar-dasar dan Aplikasinya. Malang: YA3

Faisal, S. (2006). Analisa Data dalam Penelitian Kualitatif. Makalah disampaikan pada pelatihan Penguatan Penelitian bagi Dosen Universitas Widyagama Malang. LPPM UniversitasWidya Gama Malang. 3 Oktober 2006. p. 5.

Fitzsimmons, \& Mona, J. F (2001). Service Management: Operation, Strategy and Information Technologi (p. 44). Mc.Graw Hill. New York.

Gibson, J. L., Ivancevish, J. M., Donnelly, J. H., \& Konopaske, R. (2009). Organizations: Behavior, Structure, Processes (11th ed.). New York: McGraw-Hill Irwin.

Gronroos, C. (1984). A Service Quality Model and Its Marketing Implications. European Journal of Marketing, 18(4), 36-44.

Huberman, M. A., \& Miles, M. B. (1994). Qualitative Data Analysis. New York: Sage Publications Inc.

Immegart, G. L. (1990). Leadership and Leader Behavior in Handbook of Research Education Administration. London: Longman.

Jasfar, F. (2009). Manajemen Jasa: Pendekatan Terpadu. Bogor: Ghalia Indonesia. p. 48.

Kemristekdikti. (2016). Undang-undang Republik Indonesia Nomor 20 Tahun 2003 tentang Sistem Pendidikan Nasional. Jakarta. Retrieved July 17, 2017, from http://kelembagaan.ristekdikti.go.id/2016/08

Kotler, P., \& Fox, K. F. A. (1995). Strategic Marketing for Educational Institution: Englewood Cliffs. New Jersey: Prentice Hall. p. 126.

Kotler, P. (2006). Manajemen Pemasaran Jasa: Teori dan Praktek. Alih bahasa Hendra Teguh, Roni A. Rusli. Jakarta: Prehallindo. p. 426

Lincoln, Y., \& Guba, E. G. (1985). Naturalistic Inquiry. Beverly Hills: Sage

Mantja, W. 2008. Etnografi: Desain Penelitian Kualitatif Pendidikan dan Manajemen Pendidikan. Malang: Elang Mas

Oedjoe, R. M. (2004). Keefektifan Kepemimpinan Perempuan sebagai Kepala Sekolah. Jurnal Ilmu Pendidikan. Juni 2004. Jilid II. Nomor 2: p. 191-192. http://journal.um.ac.id/.../oedjoe

Patton, M. Q. (1980). Qualitative Evaluation Methods. London: Sage Publication.Beverly Hills.

Permendiknas Nomor 49 Tahun 2007 tentang Standar Pengelolaan Lembaga Pendidikan Nonformal. Jakarta. https://hukum.unsrat.ac.id/mendiknas_49_2007 
Reeves, D. B. (2006). The Learning Leader: How to Focus School Improvement for Better Results. United State of America: ASCD Publicator. p. 34

Regina, E., Kathleen, W., \& Rajnandini, P.. (1999). Transformational Leadership in the Context of Organizational Change. Journal of Organizational Change Management, 12(2), 80-89. https://doi.org/10.1108/09534819910263631.

Spradley, J. (1980). Participant Observation. New York: Rinehart \& Winston

Sudjana. (2004). Pendidikan Nonformal: Wawasan, Sejarah Perkembangan, Filsafat, Teori Pendukung, Azas. Bandung: Falah. p. 17.

Sugiyono. (2010). Metode Penelitian Kuantitatif dan Kualitatif dan R\&D (pp. 311-329). Bandung: Alfabeta.

Sutarto. (2012). Dasar-dasar Kepemimpinan Administrasi (p. 108). Gajahmada University Press: Yogyakarta.

Suyitno, Sonhadji, A., Arifin, I., \& Ulfatin, N. (2014). Entrepreneurial Leadership of Vocational Schools Principals in Indonesia. International Journal of Learning and Development, 4(1), 23-33. Https://doi:10.5296/ijld.v4i1.4838

Usman, H. (2010). Manajemen: Teori, Praktik, dan Riset Pendidikan (3rd ed.). Yogyakarta: Bumi Akasara. p. 277.

Vijay, K. V. (1996). The Human Aspects of Project Management Human Resources Skill for The Project Manager (Vol. 2). Harper Darby, PA: Project Management Institute. www.academia.edu/vijay_K_Verma_

Widodo. (2006). Manajemen Kepegawaian II. Yogyakarta: Kanisius

Yin, R. K. (2011). Qualitative Research from Start to Finish. New York: The Guilford Press Yulk, G. (1998). Leadership in Organizations. London: Prentice-Hall International Publications.

\section{Copyright Disclaimer}

Copyright for this article is retained by the author(s), with first publication rights granted to the journal.

This is an open-access article distributed under the terms and conditions of the Creative Commons Attribution license (http://creativecommons.org/licenses/by/4.0/). 